Vol. 17 (2008): 338-350.

\title{
Energy intake and growth of weanling horses in a cold loose housing system
}

\author{
Elena Autio $^{1 *}$, Ulla Sihto ${ }^{1}$, Jaakko Mononen ${ }^{2}$ and Minna-Liisa Heiskanen ${ }^{1}$ \\ ${ }^{1}$ Equine Information Centre, PO Box 1627, FI-70211 Kuopio, Finland \\ ${ }^{2}$ University of Kuopio, Department of Biosciences, PO Box 1627, FI-70211 Kuopio, Finland \\ *e-mail: elena.autio@hevostietokeskus.fi
}

\begin{abstract}
The demand for information relating to the nutrition of horses in a cold environment is increasing with the popularity of loose housing of horses. This study examined the energy intake and growth of 10 weanling horses from November to March (22 weeks) in a loose housing system (paddock and insulated sleeping hall with deep-litter bed). The horses were measured weekly for body condition and body weight, and the feeding was adjusted according to a horse's body condition. Metabolizable energy (ME) intake was compared to Finnish (MTT 2006) and Swedish (SLU 2004) nutrient requirements for 6-12-month-old horses. ME intake $\left(75.5 \pm 11.8 \mathrm{MJ} \mathrm{d}^{-1}\right.$, mean $\left.\pm \mathrm{SD}\right)$ was on average $24.6 \%$ above the requirements. The intake varied in a non-linear fashion in the course of the winter: $y=0.086 \mathrm{x}^{2}-0.902 \mathrm{x}+71.5$, where $\mathrm{x}$ is weeks from November to March $\left(p<0.001, \mathrm{R}^{2}=0.63\right)$. Low ambient temperature increased ME intake by about $1.8 \%$ in November $(p<0.001), 0.5 \%$ in December $(p<0.001)$ and $0.2 \%$ in January $(p<0.05)$ per $1{ }^{\circ} \mathrm{C}$ decrease in ambient temperature when compared to nutrient requirements, but not in February and March. We conclude that the amount of extra energy needed decreases during the winter as the horses grow and acclimatize to the cold housing environment, i.e. as their body insulation increases. Horses gain weight at or above expected rates in cold conditions when the increased energy need is taken into account in the feeding.
\end{abstract}

Key-words: horse, housing, temperature, energy intake, growth

\section{Introduction}

In the last 20 years, there has been a great increase in scientific knowledge of the nutrition of horses (Juliand and Martin-Rosset 2004, NRC 2007).
Although the thermoregulatory mechanisms of horses have been studied to some extent (Morgan et al. 1997, Morgan 1998, Morgan et al. 2002), the nutrition of horses in a cold environment has received little study. In particular the demand for 
Vol. 17 (2008): 338-350.

information relating to the nutrition and feeding management of growing horses in a cold environment has grown with the popularity of cold loose housing in northern countries.

Cold housing may have dramatic effects on horses' energy needs. Average daily digestible energy (DE) intakes were $33 \%$ higher than maintenance energy requirement in growing horses housed outdoors in Canadian winter weather (Cymbaluk and Christison 1989a), and were increased by more than $50 \%$ in horses in severely cold conditions $\left(<-25^{\circ} \mathrm{C}\right)$ (Cymbaluk and Christison 1990). Weanling horses were reported to gain weight normally in the cold when fed readily digested diets ad libitum (Cymbaluk and Christison 1989a), but when horses were fed according to nutrient recommendations, cold-housed $\left(-5^{\circ} \mathrm{C}\right)$ horses gained weight about $30 \%$ slower than warm-housed $\left(10^{\circ} \mathrm{C}\right)$ horses (Cymbaluk 1990). Growing horses were found to require about $1-2 \%$ more DE per $1{ }^{\circ} \mathrm{C}$ decrease below the lower critical temperature (LCT) of $0{ }^{\circ} \mathrm{C}$ to guarantee maintenance and growth in the cold. Mature horses required about $2.5 \%$ more ME for maintenance per $1{ }^{\circ} \mathrm{C}$ decrease below the LCT of $-15^{\circ} \mathrm{C}$ (McBride et al. 1985).

Nutrient requirements of horses have been determined in the US by the National Research Council (NRC 2007). In Europe, several different energy systems and nutrient requirements have been performed and published for horses (INRA 1990, GfE 1994, CVB 2004, SLU 2004, MTT 2006). In Northern Europe, e.g. in Sweden and Finland, the nutrient requirements commonly used are SLU (2004) and MTT (2006) requirements, of which the SLU requirements include guidelines for feeding horses in a cold environment. Feeding of growing horses according to the requirements is important, since imbalanced nutrition may cause weight loss or weight gain, retard or increase growth rate, weaken the bones and increase the risk of developmental orthopaedic diseases (Thompson et al. 1988, Cymbaluk et al. 1989a, Cymbaluk et al. 1989b, Cymbaluk et al. 1990, Donabédian et al. 2006, NRC 2007). In practice, balancing nutrient intake is difficult for horse breeders because they do not often know the nutrient concentrations of the feeds they use and do not take into account differences in nu- trient requirements for growing horses of various ages in the feeding strategies (Gibbs and Cohen 2001). Cold housing makes balancing even more difficult, since it is important to ensure adequate energy intake for maintenance and growth, and to avoid excess intake of nutrients. For example, in Central Finland, weanling horses' body condition has been noticed to decrease quite often in cold loose housing conditions (E. Lappeteläinen, DVM, personal communication, August 16, 2007).

In this preliminary study, the objective was to observe the level of energy intake and growth of weanling horses in a cold loose housing system, when the feeding was balanced to meet energy need in the cold by adjusting energy intake from silage and concentrates according to the horses' body condition. Energy intake was compared to the Finnish (MTT 2006) and Swedish (SLU 2004) nutrient requirements.

\section{Material and methods}

\section{Animals and housing}

The study was carried out between November 2002 and March 2003 (22 weeks) in a loose housing system at the Vocational Institute of Ylä-Savo in Kiuruvesi, Finland (latitude $63^{\circ} 29^{\prime}$ N, longitude $26^{\circ} 38^{\prime} \mathrm{E}$ ). Ten weanling horses participated in the study. Seven of them were Standardbred horses (SB) (three fillies and four colts) and three were Finnish coldblood horses (FC), i.e. Finnhorses, (two fillies and one colt). In the autumn before weaning, the horses were housed in box stables at night and kept in outdoor paddocks in the day. The horses were weaned and brought to the loose house in October. The age of the horses ranged from 118 to $224 \mathrm{~d}$ (average $160 \pm 31$ d, i.e. 5.3 months) at the beginning of the study in November. The horses were vaccinated and treated against internal parasites regularly.

The loose house was an unheated, insulated facility consisting of two identical sleeping halls with a deep-litter bed, roofed entrance shelters and 
Autio, E. et al. Energy intake of loose housed weanling horses

paddocks. The facilities were the same as those described in the study by Autio and Heiskanen (2005). The ambient temperature $\left(T_{a}\right)$ in the sleeping halls was a few degrees higher than the outdoor $\mathrm{T}_{\mathrm{a}}$. At night-time (16:00-07:00), the horses were kept in two groups (five horses in each group), which spent the evenings and nights on their own sides of the facility. In the daytime (07:00-16:00) both groups had free access to a large paddock ( $0.64 \mathrm{ha})$; in the evenings and nights, groups had access to smaller paddocks ( $0.08 \mathrm{ha})$. In the results and analyses, both groups were combined. The daily average $\mathrm{T}_{\mathrm{a}}$ 's were obtained from the meteorological recording station at Vieremä (Finnish Meteorological Institute), located about $30 \mathrm{~km}$ from the study site. The average daily $\mathrm{T}_{\mathrm{a}}$ of the study site correlated closely with the $\mathrm{T}_{\mathrm{a}}$ recordings obtained from the meteorological recording station (mean difference $0.1{ }^{\circ} \mathrm{C}$ ).

\section{Feeds and feeding}

The diet was composed of hay and silage supplemented by concentrates (Table 1 ). The horses were fed hay in one group during the daytime while silage and concentrates were individually fed during the daytime. Timothy hay was fed ad libitum outdoors in the paddocks. Hay was placed in off-the-ground feeding troughs fixed to the wall outside the sleeping halls. Intake was daily determined by measuring refusals every morning before the subsequent distribution. Silage was fed twice a day (0600 and 1600) and concentrates (oats, protein supplement (Racing Protein, Suomen Rehu Oy, Helsinki, Finland), concentrate supplement (Mella leseleike, Suomen Rehu Oy, Helsinki, Finland), mineral and vitamin supplement (Steel Joint, Oy Steel Joint Ltd, Lahti, Finland)) three times a day (0600, 1030 and 1600) indoor in the sleeping halls. The horses were tied to the wall beside the feed buckets inside the halls during the feeding of concentrates and silage. Salt blocks and automatic waterers were located inside the halls. Refusals of all feeds were daily determined and deducted from consumption.

The nutrient compositions of hay, silage and oats were analysed by the regional laboratory of Valio Oy (Lapinlahti, Finland) (Artturi -feed analysis) by the standard NIR-method (Nousiainen et al. 2003) (Table 1). The nutrient compositions of protein and concentrate supplement were analysed by the laboratory of Suomen Rehu Oy (Turku/ Seinäjoki, Finland) by the standard methods (Ministry of Agriculture and Forestry 2006) (dry matter,

Table 1. Nutrient composition and feed values of feeds used in the study (DM basis).

\begin{tabular}{|c|c|c|c|c|c|c|}
\hline & Hay & Silage & Oats & $\begin{array}{l}\text { Protein } \\
\text { supplement }\end{array}$ & $\begin{array}{l}\text { Concentrate } \\
\text { supplement }^{1}\end{array}$ & $\begin{array}{l}\text { Mineral and vitamin } \\
\text { supplement }\end{array}$ \\
\hline $\mathrm{DM}, \mathrm{g} \mathrm{kg}^{-1}$ & 830 & 600 & 860 & 890 & 880 & 850 \\
\hline DCP, $\mathrm{g} \mathrm{kg}^{-1}$ & 93 & 130 & 126 & 202 & 100 & \\
\hline $\mathrm{Ca}, \mathrm{g} \mathrm{kg}^{-1}$ & 3.0 & 7.6 & 0.8 & 11.2 & 4.6 & 164.7 \\
\hline $\mathrm{P}, \mathrm{g} \mathrm{kg}^{-1}$ & 2.4 & 3.2 & 3.5 & 4.5 & 1.0 & 0.4 \\
\hline Lys, $\mathrm{g} \mathrm{kg}^{-1}$ & 4.6 & 8.3 & 3.3 & 48.3 & & \\
\hline $\mathrm{FFU}, \mathrm{kg}^{-1}$ & 0.77 & 0.84 & 1.05 & 1.12 & 1.25 & \\
\hline $\mathrm{ME}, \mathrm{MJ} \mathrm{kg}^{-1}$ & 9.0 & 9.8 & 12.3 & 13.1 & 14.6 & \\
\hline
\end{tabular}

$\mathrm{DM}=$ dry matter, $\mathrm{DCP}=$ digestible crude protein, $\mathrm{Lys}=$ lysine, $\mathrm{FFU}=$ Finnish feed unit, $\mathrm{ME}=$ metabolizable energy.

${ }^{1}$ Consisting of wheat bran, sugar beet and molasses. 
Vol. 17 (2008): 338-350.

DM): 71/393/ETY, crude protein (CP): 93/28/ETY, calcium $(\mathrm{Ca})$ and phosphorus $(\mathrm{P})$ : plasma emission spectrometry, lysine (Lys): 98/64/EY). The laboratories of Valio Oy and Suomen Rehu Oy determined feed values (Finnish feed unit (FFU) and digestible crude protein (DCP)) of the forages and concentrates by using MTT (2006) formulas and feed tables. The nutrient composition of mineral and vitamin supplement was analysed by Outokumpu Mining Services (Outokumpu Oyj, Espoo, Finland) by the standard x-ray fluorescence spectroscopy (XRF) method.

In October, the horses were brought to the loose house, where they were fed a diet sufficient to supply the nutrient requirements of 6-12-monthold horses expected to reach a mature BW of 500 $\mathrm{kg}$ (MTT 2006) until the beginning of the study (transitional period). The amount of silage and concentrates fed was adjusted according to voluntary hay intake; the nutrients received from hay and the amount of other feeds fed was calculated so that the nutrient requirements of ME, DCP, Ca, P and Lys were met. After the beginning of the study in early November, the horses' body condition score (BCS), which reflects a horse's energy status, was assessed once a week on a subjective scale of one (poor: Animal extremely emaciated. Spinous processes, ribs, tailhead, tuber coxae and ischii projecting prominently. Bone structure of withers, shoulders and neck easily noticeable. No fatty tissue can be felt.) to nine (extremely fat: Obvious cease down back. Patchy fat appearing over ribs. Bulging fat around tailhead, along withers, behind shoulders and along neck. Fat along inner thighs may rub together. Flank filled with fat.) (Henneke et al. 1983). Moderate BCS (Back level. Ribs cannot be visually distinguished but can be easily felt. Fat around tailhead beginning to feel spongy. Withers appear rounded over spinous processes. Shoulders and neck blend smoothly into body), i.e. a score of 5 , was regarded as an indicator of adequate energy intake and was the target score. Thus, according to each horse's BCS, energy intake was adjusted individually by changing the amount of silage and/or concentrates fed to the horse. If a horse became leaner than the target score, the amount of silage and/or concentrates fed was increased, and if a horse became fatter than the target score, the amount was decreased. At the same time, the intakes of other nutrients (DCP, Ca, P, Lys) were adjusted so that at least minimum nutrient requirements were met.

During the experiment, the diets were revised on average twice a month according to BCS. Nutrient intake was calculated using Hopti software (Equine Information Centre, Kuopio, Finland). For energy, intake was calculated in ME according to SLU (2004) system and in FFU according to MTT (2006) system. The energy need was determined on the basis of the performance of the growing horses during the experiment. ME intake was compared to the prediction of energy intake, which was based on the MTT (2006) and SLU (2004) requirements.

\section{Body weight and BCS measurements}

The horses were measured weekly for body weight (BW) and wither height (distance from the ground to the highest point of the withers). The wither height measurements were started on the first day of the study. The BW measurements were started in December due to technical problems with the weighing scale. The growth of the SB horses was compared with the growth data presented in Sandgren et al. (1993) and the growth of the FC horses with the growth data presented in Ahtila and Saastamoinen (2005), and Saastamoinen and Koskinen (1993).

\section{Statistical analyses}

Statistical analyses were made using SPSS 14.0 for Windows. The average weekly energy intakes of the horses were compared with the energy requirements by the One-Sample t-Test. BCS was compared with the target score by the non-parametric Wilcoxon Signed-Rank test. Since the comparisons were made separately for repeated measurements, the p-values were multiplied by the Bonferroni correction. The effect of time (Model 1) and $\mathrm{T}_{\mathrm{a}}$ (Model 2) on daily total (MJ) and mass-specific (MJ per $100 \mathrm{~kg} \mathrm{BW}$ ) 


\section{AGRICULTURAL AND FOOD SCIENCE}

Autio, E. et al. Energy intake of loose housed weanling horses

ME intake was tested using the Linear Mixed Model (LMM):

Model 1: $\mathrm{Y}_{\mathrm{ij}}=\alpha+\beta \times$ time $+\theta \times$ time $^{2}+\gamma_{\mathrm{i}}+\varepsilon_{\mathrm{ij}}$ where, $\mathrm{Y}_{\mathrm{ij}}=$ daily ME intake for animal $\mathrm{i}$ at week $\mathrm{j}, \mathrm{i}=$ animal $1 \ldots 10, \mathrm{j}=$ week $1 \ldots 22$ (time), $\alpha=$ intercept, $\beta=$ regression coefficient for the linear trend, $\theta=$ regression coefficient for the polynomial $\left(2^{\text {nd }}\right.$ order $)$ trend, $\gamma_{i}=$ random effect for $i^{\text {th }}$ animal, $\varepsilon_{\mathrm{ij}}=$ residual for the $\mathrm{i}^{\text {th }}$ animal at time $\mathrm{j}$. Random effects $\gamma_{\mathrm{i}}$ and residuals $\varepsilon_{\mathrm{ij}}$ were assumed normally distributed.

Model 2: $\mathrm{Y}_{\mathrm{ij}=} \alpha+\beta \times$ temp $_{\mathrm{j}}+\theta \times$ time $_{\mathrm{j}}+\gamma \times$ temp. $\times$ time $+\Delta_{\mathrm{i}}+\varepsilon_{\mathrm{ij}}$

where, $\mathrm{Y}_{\mathrm{ij}}=$ daily ME intake for animal $\mathrm{i}$ at week $\mathrm{j}$, $\mathrm{i}=$ animal $1 \ldots 10, \mathrm{j}=$ day $1 \ldots 154, \alpha=$ intercept,$\beta=$ regression coefficient for temperature, $\theta=$ regression coefficient for time, $\gamma=$ interaction of temperature and time, $\Delta_{\mathrm{i}}=$ random effect for $\mathrm{i}^{\text {th }}$ animal, $\varepsilon_{\mathrm{ij}}=$ residual for the $\mathrm{i}^{\text {th }}$ animal at day $\mathrm{j}$.

The effect of $\mathrm{T}_{\mathrm{a}}$ on daily ME intake was tested by the LMM, where $T_{a}$ was tested as a continuous or categorical variable. The aim of the latter analysis was to see whether the LCT of $-11^{\circ} \mathrm{C}$ defined for cold-housed weanling horses in earlier studies (Cymbaluk and Christison 1989a, Autio et al. 2007) could also be valid for the weanling horses in the present study. Therefore, in the mixed model, $\mathrm{T}_{\mathrm{a}}$ 's were divided into two categories: warm $\left(\mathrm{T}_{\mathrm{a}}>\right.$ $\left.-11^{\circ} \mathrm{C}\right)$ and cold $\left(\mathrm{T}_{\mathrm{a}}<-11^{\circ} \mathrm{C}\right)$.

\section{Results}

\section{Feed intake}

The voluntary hay intake of the horses was on average $4.4 \pm 1.2 \mathrm{~kg} \mathrm{DM} \mathrm{d}^{-1}$ (mean $\left.\pm \mathrm{SD}\right)(1.5 \pm$ $0.4 \mathrm{~kg}$ DM per $100 \mathrm{~kg} \mathrm{BW}$ ); it increased during the study being $3.7 \pm 1.1 \mathrm{~kg} \mathrm{DM} \mathrm{d}^{-1}$ in November, $4.0 \pm 0.8 \mathrm{~kg} \mathrm{DM} \mathrm{d}^{-1}(1.5 \pm 0.3 \mathrm{~kg} \mathrm{DM}$ per 100 $\mathrm{kg} \mathrm{BW})$ in December, $4.3 \pm 0.9 \mathrm{~kg} \mathrm{DM} \mathrm{d}^{-1}(1.5 \pm$
$0.3 \mathrm{~kg}$ DM per $100 \mathrm{~kg} \mathrm{BW}$ ) in January, $4.3 \pm 0.9$ $\mathrm{kg} \mathrm{DM} \mathrm{d}^{-1}(1.4 \pm 0.3 \mathrm{~kg}$ DM per $100 \mathrm{~kg} \mathrm{BW})$ in February and $5.6 \pm 1.1 \mathrm{~kg} \mathrm{DM} \mathrm{d}^{-1}(1.8 \pm 0.4 \mathrm{~kg}$ $\mathrm{DM}$ per $100 \mathrm{~kg} \mathrm{BW})$ in March. Silage was given on average $1.6 \pm 0.4 \mathrm{~kg} \mathrm{DM} \mathrm{d}^{-1}$, oats $1.0 \pm 0.2 \mathrm{~kg}$ $\mathrm{DM} \mathrm{d}^{-1}$, protein supplement $0.5 \pm 0.2 \mathrm{~kg} \mathrm{DM} \mathrm{d}^{-1}$, concentrate supplement $0.09 \pm 0 \mathrm{~kg} \mathrm{DM} \mathrm{d}^{-1}$ and mineral and vitamin supplement $0.01 \pm 0.01 \mathrm{~kg}$ $\mathrm{DM} \mathrm{d}^{-1}$. The forage: concentrate ratio ranged from $72: 28$ to $86: 14$ (DM basis) and averaged $80: 20$ during the study.

Total DM intake from forages and concentrates was on average $7.5 \pm 1.3 \mathrm{~kg} \mathrm{~d}^{-1}(2.6 \pm 0.5 \mathrm{~kg} \mathrm{DM}$ per $100 \mathrm{~kg} \mathrm{BW})$. DM intake was about $6.6 \pm 1.2$ $\mathrm{kg} \mathrm{d}^{-1}$ in November, $7.2 \pm 0.8 \mathrm{~kg} \mathrm{~d}^{-1}(2.7 \mathrm{~kg} \pm 0.4$ $\mathrm{kg}$ DM per $100 \mathrm{~kg}$ BW) in December, $7.3 \pm 0.9 \mathrm{~kg}$ $\mathrm{d}^{-1}(2.5 \mathrm{~kg} \pm 0.4 \mathrm{~kg}$ DM per $100 \mathrm{~kg}$ BW $)$ in January, $7.3 \pm 0.9 \mathrm{~kg} \mathrm{~d}^{-1}(2.4 \mathrm{~kg} \pm 0.4 \mathrm{~kg}$ DM per 100 $\mathrm{kg} \mathrm{BW})$ in February and $9.0 \pm 1.2 \mathrm{~kg} \mathrm{~d}^{-1}(2.8 \mathrm{~kg} \pm$ $0.5 \mathrm{~kg}$ DM per $100 \mathrm{~kg} \mathrm{BW}$ ) in March.

\section{Energy intake}

ME intake was on average $75.5 \pm 11.8 \mathrm{MJ} \mathrm{d}^{-1}$ (mean $\pm \mathrm{SD})(26.0 \pm 4.5 \mathrm{MJ}$ per $100 \mathrm{~kg} \mathrm{BW})$ during the study, which is about $30 \%$ above the MTT (2006) requirements and SLU (2004) requirements for slow growth and about $15 \%$ above the SLU (2004) requirements for rapid growth (Fig. 1). ME intake increased with time and differed from the MTT requirements and the SLU requirements for slow growth from week 2 onwards ( $p<0.001)$, and from the SLU requirements for rapid growth approximately from week 8 onwards $(p<0.05)$.

$\mathrm{T}_{\mathrm{a}}$ increased the total ME intake of the horses by about $0.5 \%(0.3 \mathrm{MJ})$ per $1{ }^{\circ} \mathrm{C}$ increase in $\mathrm{T}_{\mathrm{a}}$ during the whole study period $(p<0.001, \mathrm{LMM})$, but the effect of $T_{a}$ varied in the course of the winter (Fig. 2). In November total ME intake increased by $1.8 \%(1.1 \mathrm{MJ})(p<0.001)$, in December by $0.5 \%(0.3 \mathrm{MJ})(p<0.001)$ and in January by $0.2 \%(0.1 \mathrm{MJ})(p<0.05)$ per $1{ }^{\circ} \mathrm{C}$ decrease in $\mathrm{T}_{\mathrm{a}}$. In February and March, ME intake increased by $0.7 \%(0.4 \mathrm{MJ})$ and $1.3 \%(0.8 \mathrm{MJ})$, respectively, per $1{ }^{\circ} \mathrm{C}$ increase in $\mathrm{T}_{\mathrm{a}}(p<0.001)$. Mass-specific 
Vol. 17 (2008): 338-350.
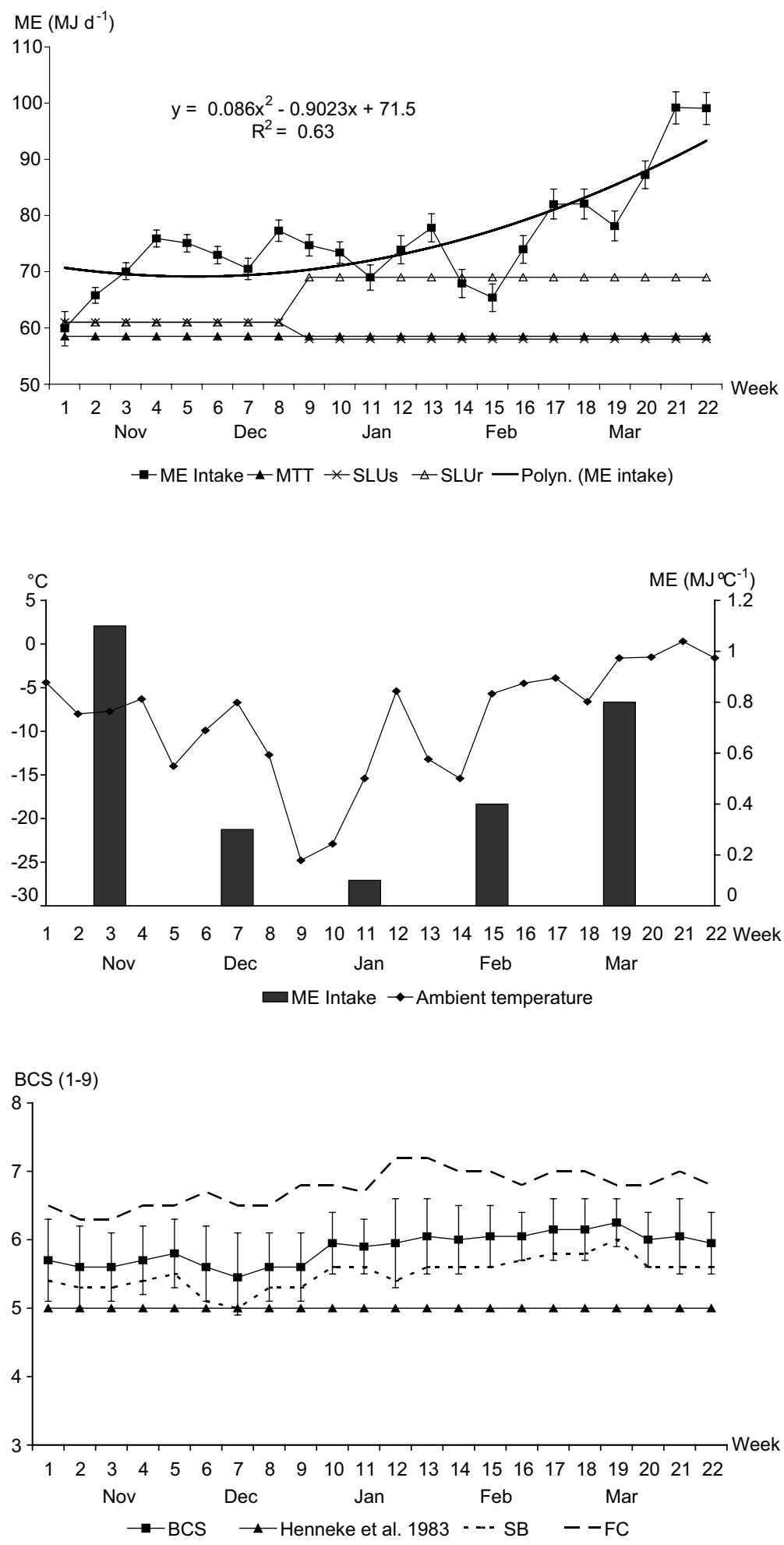

Fig. 1. Mean weekly metabolizable energy (ME) intake $\left(\mathrm{MJ} \mathrm{d}^{-1}\right)$ of the weanling horses compared with the nutrient requirements of MTT (2006) and SLU (2004) for slow growth (SLUs), and SLU (2004) for rapid growth (SLUr).

Fig. 2. Mean weekly outdoor temperature and the increase in ME intake per $1{ }^{\circ} \mathrm{C}$ degree decrease in ambient temperature (Nov, Dec, Jan) and per 1 ${ }^{\circ} \mathrm{C}$ degree increase in ambient temperature (Feb, Mar) in different months.
Fig. 3. Mean weekly body condition score (BCS) of the weanling horses $(\mathrm{SB}=$ Standardbreds, FC $=$ Finnish coldblood horses). 


\section{AGRICULTURAL AND FOOD SCIENCE}

Autio, E. et al. Energy intake of loose housed weanling horses

ME intake increased in December by $0.29 \%(0.06$ MJ per $100 \mathrm{~kg} \mathrm{BW})(p<0.01)$ and in January by $0.34 \%(0.07 \mathrm{MJ}$ per $100 \mathrm{~kg} \mathrm{BW})(p<0.01)$ per 1 ${ }^{\circ} \mathrm{C}$ decrease in $\mathrm{T}_{\mathrm{a}}$. In February, mass-specific ME intake increased by $0.39 \%(0.08 \mathrm{MJ}$ per $100 \mathrm{~kg}$ BW) $(p<0.01)$ per $1{ }^{\circ} \mathrm{C}$ increase in $\mathrm{T}_{\mathrm{a}}$.

$\mathrm{T}_{\mathrm{a}}$ affected ME intake when $\mathrm{T}_{\mathrm{a}}$ was a categorical variable in the statistical models (LMM). In the whole study period, total ME intake was on average $0.5 \%(0.3 \mathrm{MJ})$ higher at $\mathrm{T}_{\mathrm{a}}$ above $-11^{\circ} \mathrm{C}$ than at $\mathrm{T}_{\mathrm{a}}$ below $-11{ }^{\circ} \mathrm{C}(p<0.05)$, but the magnitude of the effect varied between the months. In November, ME intake was on average $16.1 \%(10.8$ $\mathrm{MJ})$, and in December, 6.8 \% (4.7 MJ) $(p<0.001)$ higher at $\mathrm{T}_{\mathrm{a}}$ below $-11{ }^{\circ} \mathrm{C}$ than at $\mathrm{T}_{\mathrm{a}}$ above -11 ${ }^{\circ} \mathrm{C}$. In February, ME intake was on average 4.7 $\%$ (3.3 MJ) higher at $\mathrm{T}_{\mathrm{a}}$ above $-11{ }^{\circ} \mathrm{C}$ than at $\mathrm{T}_{\mathrm{a}}$ below $-11{ }^{\circ} \mathrm{C}(p<0.01)$. Mass-specific ME intake was on average $6.3 \%(1.3 \mathrm{MJ})$ and $4.4 \%(0.9 \mathrm{MJ})$ higher at $\mathrm{T}_{\mathrm{a}}$ below $-11^{\circ} \mathrm{C}$ than at $\mathrm{T}_{\mathrm{a}}$ above $-11^{\circ} \mathrm{C}$ in December and January, respectively.

DCP, $\mathrm{Ca}$ and $\mathrm{P}$ intakes followed ME intake during the study period, and were, therefore highest in late winter. The average DCP intake was $848 \pm 128 \mathrm{~g} \mathrm{~d}^{-1}(293 \pm 53$ g per $100 \mathrm{~kg} \mathrm{BW})$ during the study. DCP to ME ratio was $11 \mathrm{~g}$ DCP per MJ ME. The average Lys intake was $58.8 \pm 9.1 \mathrm{~g}$ $\mathrm{d}^{-1}(19.6 \pm 4.5 \mathrm{~g}$ per $100 \mathrm{~kg} \mathrm{BW})$, and Lys to ME ratio $0.8 \pm 0.1 \mathrm{~g}$ per $\mathrm{MJ} \mathrm{ME}$. The average $\mathrm{Ca}$ and $\mathrm{P}$ intakes were $43.1 \pm 7.8 \mathrm{~g} \mathrm{~d}^{-1}(14.8 \pm 2.4 \mathrm{~g}$ per $100 \mathrm{~kg} \mathrm{BW})$ and $24.9 \pm 5.1 \mathrm{~g} \mathrm{~d}^{-1}(8.4 \pm 1.3 \mathrm{~g}$ per $100 \mathrm{~kg} \mathrm{BW}$ ), respectively, during the study. The $\mathrm{Ca}: \mathrm{P}$ ratio ranged from 1.6 to 1.8 .

\section{Body weight and $B C S$}

Individual growth curves of the weanling horses are presented in Fig. 4. Median BW of the horses was $262 \mathrm{~kg}$ at 6 months of age, $290 \mathrm{~kg}$ at 7 months of age, $296 \mathrm{~kg}$ at 8 months of age, $319 \mathrm{~kg}$ at 9 months of age and $340 \mathrm{~kg}$ at 10 months of age. Median average daily gain (ADG) decreased during the study being $0.82 \mathrm{~kg} \mathrm{~d}^{-1}$ at 6 months of age, $0.71 \mathrm{~kg} \mathrm{~d}^{-1}$ at 7 months of age, $0.64 \mathrm{~kg} \mathrm{~d}^{-1}$ at 8 months of age and $0.38 \mathrm{~kg} \mathrm{~d}^{-1}$ at 9 months of age. Median ADG of the horses during the whole study period was $0.61 \mathrm{~kg} \mathrm{~d}^{-1}$. Median BCS was 5.5 from November to January and 6.0 from February to March, and 5.5 during the whole study period. The BCS differed from the target score of 5 in weeks 1,5,10 and 11, and from week 13 onwards $(p<0.05)$ (Fig. 3).
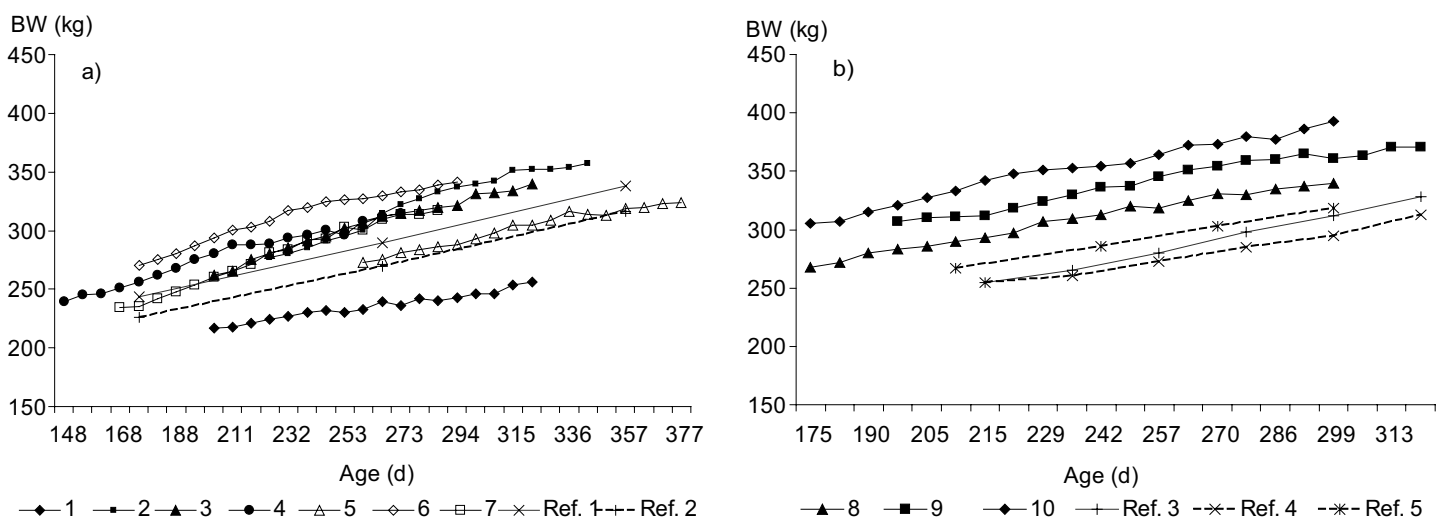

Fig. 4. Individual growth curves (body weight BW, kg) of the weanling Standardbred (1-7) (a) and Finnish coldblood horses (8-10) (b) compared with the reference curves (Ref. 1 = Sandgren et al. 1993: max., Ref. $2=$ Sandgren et al. 1993: min., Ref. 3 = Saastamoinen and Koskinen 1993: max, Ref. 4 = Saastamoinen and Koskinen 1993: min, Ref. 5: Ahtila and Saastamoinen 2005). 


\section{AGRICULTURAL AND FOOD SCIENCE}

Vol. 17 (2008): 338-350.

\section{Discussion}

The present preliminary study examined energy intake and growth of weanling horses in a cold loose housing system. In the examination, management practices followed general loose housing practices, where horses are group-housed and fed forages ad libitum. In addition, the energy intake of the horses was adjusted according to common practice in field conditions, i.e. on the basis of predicted energy requirements of growing horses determined by SLU (2004) and MTT (2006), and on the basis of BCS. Therefore, energy intake was not adjusted according to actual BW and predicted BW of the following study period, as was done, for example, in the study of Donabédian et al. (2006). The French nutritional models used in the study of Donabédian et al. (2006) have been established by INRA (1990). In these French models, the total energy requirement of a growing horse is determined on the basis of actual metabolic BW, ADG and composition of weight gain (Martin-Rosset et al. 1994). In the present study, MTT (2006) and SLU (2004) requirements were used because these requirements are generally used in the Nordic countries. In these requirements, the predicted energy requirements of a growing horse is the sum of the energy needed for maintenance (based on average, estimated BW of a growing horse expected to reach a mature BW of $500 \mathrm{~kg}$ ) and the energy needed for gain (based on age and average, estimated ADG of a growing horse expected to reach a mature BW of $500 \mathrm{~kg}$ ) (SLU 2004). Because energy adjustments were based on predicted energy requirements and actual $\mathrm{BCS}$, and the composition of diet was not constant during the study, it is possible that this adjustment method may have slightly overestimated the energy requirements of the weanling horses, and thus also the effect of $\mathrm{T}_{\mathrm{a}}$ on energy need. It should also be noted that the voluntary activity of the horses in a loose housing system may affect their energy need. However, in the present study, the weanling horses were known to be quite inactive during the winter (see Autio and Heiskanen 2005).

The energy intake $\left(75.5 \pm 11.8 \mathrm{MJ} \mathrm{d}^{-1}, 26.0 \pm\right.$ 4.5 MJ per $100 \mathrm{~kg} \mathrm{BW}$ ) of the weanling horses in the present study was on average $24.6 \%$ above the MTT (2006) and SLU (2004) predicted energy requirements for weanling horses expected to reach a mature BW of $500 \mathrm{~kg}$, with the horses being fed good quality hay ad libitum and the amount of silage and concentrates being adjusted according to the horse's BCS. Also DCP, Ca and P intakes were mostly above the requirements because their intakes followed energy intake. Of all the measured nutrient intakes, $\mathrm{Ca}$ and $\mathrm{P}$ intakes and $\mathrm{Ca}: \mathrm{P}$ ratio remained most within the limits of the requirements, perhaps due to the adjustment of the amount of mineral supplement fed with the aid of the equine feeding program. Ca intake $\left(43.1 \pm 7.8 \mathrm{~g} \mathrm{~d}^{-1}, 14.8\right.$ $\pm 2.4 \mathrm{~g}$ per $100 \mathrm{~kg} \mathrm{BW}$ ) was on average $30 \%$ above the Ca requirements (MTT 2006: $33 \mathrm{~g} \mathrm{~d}^{-1}$, SLU 2004: 29-37 $\left.\mathrm{g} \mathrm{d}^{-1}\right)$, and P intake (24.9 \pm 5.1 $\mathrm{g} \mathrm{d}^{-1}, 8.4 \pm 1.3 \mathrm{~g}$ per $100 \mathrm{~kg} \mathrm{BW}$ ) was on average $23 \%$ above the P requirements (MTT 2006: $22 \mathrm{~g}$ $\mathrm{d}^{-1}$, SLU 2004: 17-21 $\mathrm{g} \mathrm{d}^{-1}$ ) for horses expected to reach a mature BW of $500 \mathrm{~kg}$. DCP intake $(848$ $\pm 128 \mathrm{~g} \mathrm{~d}^{-1}, 293 \pm 53 \mathrm{~g}$ per $\left.100 \mathrm{~kg} \mathrm{BW}\right)$ was on average $60 \%$ above the DCP requirements (MTT 2006: $500 \mathrm{~g} \mathrm{~d}^{-1}$, SLU 2004: 493-610 $\left.\mathrm{g} \mathrm{d}^{-1}\right)$. Also the average DCP to ME ratio (11g DCP per MJ $\mathrm{ME})$ and Lys to ME ratio $(0.8 \pm 0.1 \mathrm{~g}$ per MJ ME) were slightly higher than the requirements (SLU 2004: 8.5-10.0 g DCP per MJ ME, 0.5-0.6 g Lys per MJ ME). These facts indicate that the protein content of the feeds used in the present study was too high. When considering the results, it should be noted that, since the horses were group housed, daily hay intake values were calculated from group hay intake and were uniform for all of the horses. Variation in the total nutrient intakes (consisting of nutrient intakes from hay, silage and concentrates) is therefore slightly underestimated in the results .

Both the total and mass-specific ME intakes of the weanling horses were increased by low $\mathrm{T}_{\mathrm{a}}$ in early winter but not in late winter, which may reflect the progressive acclimatization of the horses to their cold housing environment. Therefore, the cold resistance of the horses apparently improved during the winter. Since the energy intake in relation to $T_{a}$ decreased, this signifies that improved cold resistance resulted from increased body insu- 


\section{AGRICULTURAL AND FOOD SCIENCE}

Autio, E. et al. Energy intake of loose housed weanling horses

lation. However, it is unclear whether the improved insulation was caused by increasing coat insulation or by the decreasing ratio between heat dissipating surface area and heat productive/retaining body mass of the growing horses, or by both of these.

The results are in accordance with an earlier study, where $\mathrm{T}_{\mathrm{a}}$ affected the DE intake of weanling horses in early winter but not in late winter (Cymbaluk and Christison 1989a). In the present study, total ME intake increased by $1.8 \%$ in November, $0.5 \%$ in December and $0.2 \%$ in January per 1 ${ }^{\circ} \mathrm{C}$ decrease in $\mathrm{T}_{\mathrm{a}}$. During these months, the lowest daily $\mathrm{T}_{\mathrm{a}}$ was generally near or lower than the LCT of $-11^{\circ} \mathrm{C}$ determined for cold-housed weanling horses (Cymbaluk and Christison 1989a, Autio et al. 2007), and the amount of concentrates fed had to be increased to maintain the moderate BCS of the horses. In the present study, the two-category analysis showed that the LCT also was approximately $-11{ }^{\circ} \mathrm{C}$ at least in early winter, since ME intakes were higher at $\mathrm{T}_{\mathrm{a}}$ below $-11{ }^{\circ} \mathrm{C}$ than at $\mathrm{T}_{\mathrm{a}}$ 's above $-11{ }^{\circ} \mathrm{C}$. The results indicate that the winter period has an effect on the energy needs of the weanling horses in a cold housing environment and that the climatic energy need is highest in early winter. Accordingly, a drop in $\mathrm{T}_{\mathrm{a}}$ to $-20{ }^{\circ} \mathrm{C}$ increased the energy need of the horses by approximately $18 \%$ in November, $5 \%$ in December and $2 \%$ in January. In February and March, daily $\mathrm{T}_{\mathrm{a}}$ fluctuations had little effect on energy need because $\mathrm{T}_{\mathrm{a}}$ was mostly above the LCT. In addition, the increasing energy need of the weanling horses in late winter, which was apparently related to increasing BW (maintenance energy need increases) and changing composition of weight gain (the protein content of gain decreases and fat content increases as age increases) (Frape 1998, NRC 2007), probably outweighed the effect of $\mathrm{T}_{\mathrm{a}}$.

The increase (i.e. $0.2-1.8 \%$ more energy per $1{ }^{\circ} \mathrm{C}$ decrease in $\mathrm{T}_{\mathrm{a}}$ ) in energy need in $\mathrm{T}_{\mathrm{a}}$ below the LCT in the present study is in accordance with earlier studies (Cymbaluk 1990, Cymbaluk et al. 1989a, but see also Cymbaluk and Christison 1989a). Increased energy need in a cold housing environment is taken into account in the SLU (2004) energy requirements. According to the SLU, ad libitum fed growing horses need $1.4 \%$ more maintenance energy in a cold environment for each $1{ }^{\circ} \mathrm{C}$ decrease in $\mathrm{T}_{\mathrm{a}}$ below $-11^{\circ} \mathrm{C}$. The present study confirms that SLU's advice is valid in early winter, but may lead to excess weight gain if followed rigidly throughout the winter.

In contrast to the early winter, the ME intake of the horses in late winter increased as $\mathrm{T}_{\mathrm{a}}$ increased, which resulted from increased voluntary hay intake. DM intake from forages was about $2 \%$ of BW per day during the study except in March, when DM intake increased to $2.4 \%$ of BW per day. Therefore, average daily DM and ME intakes increased with time (age). This is in agreement with earlier studies in growing horses, in which daily DM and DE intakes increased with BW and were accordingly related to age (Cymbaluk and Christison 1989a, Cymbaluk et al. 1989a). Increasing body size and changes in the composition of weight gain apparently explain the increased energy need of the weanling horses, and thus increased energy intake in late winter (NRC 2007). The horses were also probably adapted to large feed intake during the winter. Nevertheless, the increased DM intake in late winter at warmer $\mathrm{T}_{\mathrm{a}}$ caused the positive relation of ME intake to $T_{a}$, in opposition to the early winter, when the relation was negative.

In February (week 15), the horses reached on average 9 months of age, after which the rate of weight gain declines (Frape 1998). At the same time, $\mathrm{T}_{\mathrm{a}}$ was rising. Increased hay intake combined with the slower growth rate and higher $\mathrm{T}_{\mathrm{a}}$ meant that the BCS of the horses became greater than the target score, although the amounts of concentrates fed were reduced. The horses probably compensated for dietary energy dilution by increasing DM intake by eating more hay, as has been previously noted in forage-fed growing horses (Cymbaluk and Christison 1989b). This is supported by the fact that the average DM intake of the weanling horses (2.4 and $2.8 \mathrm{~kg}$ DM per $100 \mathrm{~kg}$ BW in February and March, respectively) was approximately the same as in ad libitum fed weanling horses in previous studies (2.5 to $3.1 \mathrm{~kg}$ DM per $100 \mathrm{~kg} \mathrm{BW}$ ) (Cymbaluk and Christison 1989a, Cymbaluk et al. 1989a). This indicates, that the reduction in the concentrates fed was not sufficient to prevent a rise in BCS and excess nutrient intake, and that, 
Vol. 17 (2008): 338-350.

therefore, hay intake should also have been regulated. Feeding forages ad libitum, so that growing horses are allowed to eat to their energy needs, is a common practice in Finnish loose housing systems. Since ad libitum-fed growing horses tend to generally have a higher nutrient intake than their nutritional needs (Cymbaluk and Christison 1989a, Cymbaluk and Christison 1989b, Cymbaluk et al. 1989a), this predisposes horses to excess nutrient intakes and imbalanced nutrition (Cymbaluk et al. 1989a, Cymbaluk et al. 1989b, Cymbaluk et al. 1990). The excess protein intake may also lead to depressed growth since the catabolism of excess amino acids consumes energy (Yoakam et al. 1978, Ahtila and Saastamoinen 2005). Therefore, ad libitum forage feeding practices in loose housing systems should be reconsidered, especially in late winter when the horses are cold-acclimatized. In early winter when the horses are not cold-acclimatized, ad libitum forage feeding is more reasonable because forages are heat productive during digestion (see Vermorel et al. 1997).

In an earlier study, weight gain in cold-housed SB horses was noted to be slower than in warmhoused horses when the increased energy need in the cold was not taken into account in the feeding (Cymbaluk 1990). When fed ad libitum, horses gained weight normally in the cold in the study of Cymbaluk and Christison (1989a). In the present study, the average BW of the SB horses was about the same as that presented for SB horses with same age and withers height $(131 \mathrm{~cm}$ and $135 \mathrm{~cm}$ at 5 and 8 months of age, respectively) in Sandgren et al. (1993). However, the FC horses weighed about $19 \%$ more than FC horses with the same withers height $(129 \mathrm{~cm}$ and $140 \mathrm{~cm}$ at 6 and 10 months of age, respectively) in the studies of Saastamoinen and Koskinen (1993) and Ahtila and Saastamoinen (2005), because the FC horses in the present study were in a moderately fleshy or fleshy body condition. The ADG of the SB horses during the study $\left(0.57 \mathrm{~kg} \mathrm{~d}^{-1}\right)$ was similar or slightly lower than in SB horses of similar age in earlier studies (Sandgren et al. 1993: 0.51-0.94 kg d ${ }^{-1}$, Andrew et al. 2006: $0.72 \mathrm{~kg} \mathrm{~d}^{-1}$, Forsmark 2006: $0.6 / 0.9 \mathrm{~kg}$ $\left.\mathrm{d}^{-1}\right)$, whereas the ADG of the FC horses $(0.62 \mathrm{~kg}$ $\left.\mathrm{d}^{-1}\right)$ was similar or slightly higher than in earlier studies in FC horses (Saastamoinen 1993: $0.56 \mathrm{~kg}$ $\mathrm{d}^{-1}$, Saastamoinen and Koskinen 1993: 0.54/0.67 $\mathrm{kg} \mathrm{d}^{-1}$, Ahtila and Saastamoinen 2005: $0.51 \mathrm{~kg} \mathrm{~d}^{-1}$ ). The weanling horses in the present study seemed to gain weight at or above expected rates in a cold housing environment when the level of energy intake was sufficient. However, it should be noted that there might be large individual variation in weight gain and that the number of horses in the present study was small. Therefore, the growth of different horse breeds in a cold housing environment should be studied more extensively in future studies.

Adjusting the energy intake of growing horses in a cold group housing system seems to be a far from simple task even under well-controlled experimental conditions due to changing circumstances. The difficulties in regulating the energy intake and BCS of horses result from the changes in both the environment (fluctuating $\mathrm{T}_{\mathrm{a}}$ ) and the animals (changes in age, level of cold acclimatization and capacity for forage intake), and from the ad libitum forage feeding. The energy intake of growing horses should be adjusted according to BW, ADG, BCS, the level of acclimatization and changing weather conditions to guarantee maintenance and normal growth in cold conditions. Although regular body condition scoring is a practical method to evaluate the adequacy of a horse's energy intake in field conditions, the method does not take into account the effect of BW and composition of weight gain on energy need. The French (INRA 1990, MartinRosset et al. 1994) horse feeding system, which is based on net energy, provides models to predict energy and protein requirements and allowances of horses using BW, ADG and BCS as variables. The French system provides thus accurate models for matching the energy requirements of growing horses. However, since systems based on ME are usually used in the Nordic countries (SLU 2004) and the NE based system lacks information about the NE values of all feeds of all classes of horses and is also more complex as it accounts for more heat losses (NRC 2007), the French model (INRA 1990, Martin-Rosset et al. 1994) is not necessarily very applicable in the Nordic countries. 


\section{AGRICULTURAL AND FOOD SCIENCE}

Autio, E. et al. Energy intake of loose housed weanling horses

This study revealed that the complete regulation of nutrient intake and BCS requires that both concentrate and forage intakes are individually controlled in loose-housed horses. This is important especially in late winter, when the weather gets warmer and the voluntary DM intake of growing horses increases. These facts pose high demands on the planning and implementation of feeding of group-housed growing horses in a cold environment to avoid overweight which is harmful for the musculoskeletal development.

\section{Conclusions}

The cold housing environment increased the energy needs of the weanling horses in early winter but not in late winter, which signifies that the horses acclimatized to the cold housing environment. Therefore, the winter period had an effect on energy need, and the amount of extra energy fed should be adjusted according to a horse's degree of acclimatization. The horses gained weight at or above expected rates indicating that they coped well with the low housing temperature when the level of feeding was sufficient.

Acknowledgements. We thank the State Provincial Office of Eastern Finland (European Social Fund) and the Employment and Economic Development Centre of Northern Savo (European Agricultural Guidance and Guarantee Fund) for providing financial support for this study, and the Vocational Institute of Ylä-Savo in Kiuruvesi, Finland, for making it possible to carry out this study. We also thank $\mathrm{PhD}$ Sanna Airaksinen and PhD Arja Lehmuskero for their comments and help, and Mr Vesa Kiviniemi for his help with the statistics.

\section{References}

Ahtila, L. \& Saastamoinen, M. 2005. Effect of nutrition on the growth curve of weanling foals. In: Juliand, V. \& Martin-Rosset, W. (eds.). The growing horse: nutrition and prevention of growth disorders. EAAP Publication 114. AE Wageningen, The Netherlands: Wageningen Aca- demic Publishers. p. 79-80.

Andrew, J.E., Kline, K.H. \& Smith, J.L. 2006. Effects of feed form on growth and blood glucose in weanling horses. Journal of Equine Veterinary Science 26: 349-355.

Autio, E. \& Heiskanen, M-L. 2005. Foal behaviour in a loose housing/paddock environment during winter. Applied Animal Behaviour Science 91: 277-288.

Autio, E., Mononen, J. \& Heiskanen, M-L. 2007. Thermographic evaluation of the lower critical temperature in weanling horses. Journal of Applied Animal Welfare Science 10: 207-216.

CVB (Centraal veevoederbureau) 2004. The EW-pa en VREP System. 31. CVB-rapport. Lelystad, The Netherlands: Centraal veevoederbureau. (in Dutch)

Cymbaluk, N.F. \& Christison, G.I. 1989a. Effects of diet and climate on growing horses. Journal of Animal Science 67: 48-59.

Cymbaluk. N.F. \& Christison, G.I. 1989b. Effects of dietary energy and phosphorus content on blood chemistry and development of growing horses. Journal of Animal Science 67: 951-958.

Cymbaluk, N.F. 1990. Cold housing effects on growth and nutrient demand of young horses. Journal of Animal Science 68: 3152-3162.

Cymbaluk, N.F. \& Christison, G.I. 1990. Environmental effects on thermoregulation and nutrition of horses. The Veterinary clinics of North America. Equine practice. 6: 355-372.

Cymbaluk, N.F., Christison, G.I. \& Leach, D.H. 1989a. Energy uptake and utilization by limit- and ad libitum-fed growing horses. Journal of Animal Science 67: 403-413.

Cymbaluk, N.F., Christison, G.I. \& Leach, D.H. 1989b. Nutrient utilization by limit- and ad libitum-fed growing horses. Journal of Animal Science 67: 414-425.

Cymbaluk, N.F., Christison, G.I. \& Leach, D.H. 1990. Longitudinal growth analysis of horses following limited and ad libitum feeding. Equine Veterinary Journal 22: 198-204.

Donabédian, M., Fleurance, G., Perona, G., Robert, C., Lepage, O., Trillaud-Geyl, C., Leger, S., Ricard, A., Bergero, D. \& Martin-Rosset, W. 2006. Effect of fast vs. moderate growth rate related to nutrient intake on developmental orhthopaedic disease in the horse. Animal Research 55: 471-486.

Forsmark, P. 2006. Fodersammansättningens betydelse för tillväxt hos häst. Examensarbete 223. Sveriges lantbruksuniversitet, Uppsala, Sweden. (in Swedish)

Frape, D. 1998. Equine Nutrition \& Feeding. 2nd ed. Oxford, UK: Blackwell Science Ltd. 564 p.

GfE (Gesellschaft für Ernährungsphysiologie der Haustiere) 1994. Empfehlung zur Energie - und Nährstoffversorgung der Pferde. Frankfurt a.M., Germany: DLG-Verlag. 63 p. (in German)

Gibbs, P.G. \& Cohen, N.D. 2001. Early management of race-bred weanlings and yearlings on farms. Journal of Equine Veterinary Science 21: 279-283.

Henneke, D.R., Potter, G.D., Kreider, J.L. \& Yeates, B.F. 1983. Relationship between condition score, physical measurements and body fat percentage in mares. Equine Veterinary Journal 15: 371-372.

INRA (Institut National de la Recherche Agronomique) 1990. L'Alimentation des Chevaux. W. Martin-Rosset (Ed.). Versailles, France: INRA Publications. 232 p. 


\section{AGRICULTURAL AND FOOD SCIENCE}

Vol. 17 (2008): 338-350.

(in French)

Juliand, V. \& Martin-Rosset, W. (Eds.) 2004. Nutrition of the performance horse. EAAP Publication 111. AE Wageningen, The Netherlands: Wageningen Academic Publishers. $160 \mathrm{p}$.

Martin-Rosset, W., Vermorel, M., Doreau, M., Tisserand, J.L. \& Andrieu, J. 1994. The French horse feed evaluation systems and recommended allowances for energy and protein. Livestock Production Science 40: 37-56.

McBride, G.E., Christopherson, R.J. \& Sauer, W. 1985. Metabolic rate and plasma thyroid hormone concentrations of mature horses in response to changes in ambient temperature. Canadian Journal of Animal Science 65: $375-382$.

Ministry of Agriculture and Forestry (2006). Asetus rehujen valvonnan järjestämisestä (3/06). Published 2.3.2006, [cited 17.6.2008]. Available at: http://wwwb.mmm.fi/el/ laki/kara/x/p060003.pdf (in Finnish)

Morgan, K. 1998. Thermoneutral zone and critical temperatures of horses. Journal of Thermal Biology 23: 59-61.

Morgan, K., Ehrlemark, A. \& Sällvik, K. 1997. Dissipation of heat from standing horses exposed to ambient temperatures between $-3^{\circ} \mathrm{C}$ and $37^{\circ} \mathrm{C}$. Journal of Thermal Biology 22: 177-186.

Morgan, K., Funkquist, P. \& Nyman, G. 2002. The effect of coat clipping on thermoregulation during intense exercise in trotters. Equine Veterinary Journal, Supplement 34: 564-567.

MTT 2006. Rehutaulukot ja ruokintasuositukset [online]. Jokioinen: MTT Agrifood Research Finland. Published 14.2.2006, [cited 9.8.2007]. Available at: https://www. mtt.fi/rehutaulukot/ (in Finnish)

Nousiainen, J., Rinne, M., Hellämäki, M. \& Huhtanen, P.
2003. Prediction of the digestibility of primary growth and regrowth grass silages from chemical composition, pepsin-cellulase solubility and indigestible cell wall content. Animal Feed Science and Technology 110: 61-74.

NRC (National Research Council) 2007. Nutrient Requirements of Horses. 6th edn. Washington, D.C., USA: National Academies Press. $341 \mathrm{p}$.

Saastamoinen, M. 1993. Factors affecting growth and development of foals and young horses. Acta Agriculturae Scandinavica 40: 387-396.

Saastamoinen, S. \& Koskinen, E. 1993. Influence of quality of dietary protein supplement and anabolic steroids on muscular and skeletal growth of foals. Animal Production 56: 135-144.

Sandgren, B., Dalin, G., Carlsten, J. \& Lundeheim, N. 1993. Development of osteochondrosis in the tarsocrural joint and osteochondral fragments in the fetlock joints of Standardbred trotters. II. Body measurements and clinical findings. Equine Veterinary Journal. Supplement 16: 48-53.

SLU (Sveriges Lantbruksuniversitet) 2004. Utfodringsrekommendationer för Häst. Uppsala, Sweden: Sveriges Lantbruksuniversitet. 43 p. (in Swedish)

Thompson, K.N., Jackson, S.G. \& Baker, J.P. 1988. The influence of high planes of nutrition on skeletal growth and development of weanling horses. Journal of Animal Science 66: 2459-2467.

Vermorel, M., Vernet, J. \& Martin-Rossett, W. 1997. Digestive and energy utilisation of two diets by ponies and horses. Livestock Production Science 51: 13-19.

Yoakam, S.C., Kirkham, W.W. \& Beeson, W.M. 1978. Effect of protein level on growth in young ponies. Journal of Animal Science 46: 983-991. 


\section{AGRICULTURAL AND FOOD SCIENCE}

Autio, E. et al. Energy intake of loose housed weanling horses

\section{SELOSTUS}

\section{Vieroitettujen varsojen energiankulutus ja kasvu kylmäpihatossa}

Elena Autio, Ulla Sihto, Jaakko Mononen ja Minna-Liisa Heiskanen

Hevostietokeskus ja Kuopion yliopisto

Hevosten pihattokasvatuksen yleistyessä tarvitaan tietoa hevosten energiantarpeesta kylmissä olosuhteissa. Tutkimuksessa selvitettiin 10 vieroitetun varsan energiankulutusta ja kasvua marras- ja maaliskuun välisenä aikana (22 viikkoa) pihatossa (jaloittelutarha ja lämpöeristetty makuuhalli, jossa kestokuivikepatja). Varsojen lihavuusaste ja paino mitattiin kerran viikossa, ja niiden ruokintaa suhteutettiin lihavuuskunnon mukaan. Muuntokelpoisen energian (ME) kulutusta verrattiin suomalaisiin (MTT 2006) ja ruotsalaisiin (SLU 2004) 6-12 kuukauden ikäisten varsojen ruokintasuosituksiin. ME:n kulutus $\left(75.5 \pm 11.8 \mathrm{MJ} \mathrm{d}^{-1}, \mathrm{ka} \pm \mathrm{SD}\right)$ oli keskimäärin $24.6 \%$ ruokintasuosituksia suurempaa.
Kulutus vaihteli talven aikana epälineaarisesti: $\mathrm{y}=$ $0.086 \mathrm{x}^{2}-0.902 \mathrm{x}+71.5$, missä $\mathrm{x}$ on viikot marraskuusta maaliskuuhun $\left(p<0.001, \mathrm{R}^{2}=0.63\right)$. Alhainen ympäristön lämpötila lisäsi ME:n kulutusta marraskuussa $1.8 \%(p<0.001)$, joulukuussa $0.5 \%(p<0.001)$ ja tammikuussa $0.2 \%(p<0.05)$ yhden asteen lämpötilan laskua kohti ruokintasuosituksiin verrattuna, mutta ei vaikuttanut kulutukseen helmi- ja maaliskuussa. Tulokset osoittavat, että lisäenergiantarve vähenee talven aikana varsojen kasvaessa ja sopeutuessa kylmään elinympäristöön, eli kehon eristyksen lisääntyessä. Varsat kasvavat normaalisti kylmissä olosuhteissa, kun lisäenergiantarve huomioidaan ruokinnassa. 